\title{
Photochemical efficiency of PSII and photoprotective pigments in seedlings and adults of two Proteaceae with different shade tolerance from the Chilean temperate rain forest
}

\author{
Eficiencia fotoquímica del PSII y pigmentos fotoprotectores en plántulas y adultos de dos \\ Proteáceas con diferente tolerancia a la sombra del bosque lluvioso templado chileno
}

\author{
MIREN ALBERDI ${ }^{1}$ *, MARJORIE REYES-DÍAZ ${ }^{2}$, RAFAEL ZÚNIIGA ${ }^{3}$, SUSAN HESS $^{4}$, LEÓN A. BRAVO $^{5}$ \\ \& LUIS J. CORCUERA ${ }^{5}$
}

\author{
${ }^{1}$ Departamento de Ciencias Químicas, Facultad de Ingeniería, Ciencias y Administración, Universidad de La Frontera, \\ Casilla 54-D, Temuco, Chile \\ ${ }^{2}$ Instituto de Agroindustria, Facultad de Ingeniería, Ciencias y Administración, Universidad de La Frontera, \\ Casilla 54-D, Temuco, Chile \\ ${ }^{3}$ Instituto de Botánica, Facultad de Ciencias, Universidad Austral de Chile, Casilla 567, Valdivia, Chile \\ ${ }^{4}$ Instituto de Química, Facultad de Ciencias, Universidad Austral de Chile, Casilla 567, Valdivia, Chile \\ ${ }^{5}$ Departmento de Botánica, Facultad de Ciencias Naturales y Oceanográficas, Universidad de Concepción, \\ Casilla 160-C, Concepción, Chile \\ * Corresponding author: malberdi@ufro.cl
}

\begin{abstract}
The seasonal variation in energy quenching parameters of photosystem II and photoprotective pigments were studied in seedlings and adults of two Proteaceae: a shade-intolerant species (Embotrium coccineum J.R. et G. Forster) and a shade-tolerant species (Lomatia ferruginea (Cav.) R. Br.). We postulate that the shade intolerant species favors photochemical energy driven processes (mainly $\mathrm{CO}_{2}$ assimilation) while the shade tolerant species exhibits higher non-photochemical energy dissipation under unfavorable conditions. Moreover, the shade tolerant species presents lower seasonal variations in these parameters that the shade intolerant species. Differences in energy dissipation should be more evident in seedlings than adults because of their contrasting light environments and temperatures are more evident at this stage. Their maximal photochemical efficiency $(\mathrm{Fv} / \mathrm{Fm})$ was in the range $0.70-0.83$. The effective photochemical efficiency (ФPSII), photochemical quenching (qP), and electron transport rate (ETR) were higher in seedlings of E. coccineum than in seedlings of $L$. ferruginea. Adults showed higher photochemical energy quenching parameters than seedlings. Nonphotochemical quenching (NPQ) was frequently similar between daily periods, seasons, species, and developmental stages, with the exception of the lowest non-photochemical quenching in seedlings of $E$. coccineum in summer. Seedlings and adults showed a larger xanthophyll cycle pool content at midday in summer than in winter, while the pool of antheraxanthin + zeaxanthin was always higher at midday. Lutein increased the most during summer. Thus, E. coccineum seedlings and adults maintained high photosynthesis, a higher fraction of open reaction centres, and higher ETR than the shade tolerant species. These differences are consistent with the ecological functions of both species: a pioneer character, higher growth rate, and wide altitudinal and latitudinal distribution of E. coccineum compared to L. ferruginea .
\end{abstract}

Key words: chlorophyll fluorescence, lutein, photosynthesis, photoprotective pigments, xanthophylls cycle.

\section{RESUMEN}

Se estudia la variación estacional en los parámetros de amortiguamiento (quenching) energético del fotosistema II y los pigmentos fotoprotectores en plántulas y adultos de dos Proteáceas con diferente tolerancia a la sombra: Embothrium coccineum J. R. et G. Foster (intolerante) y Lomatia ferruginea (Cav.) R. Br (tolerante). Se prueba la hipótesis que la especie intolerante a la sombra favorece los procesos fotoquímicos de energía conducentes a la asimilación de $\mathrm{CO}_{2}$ mientras que la tolerante a la sombra exhibe principalmente una disipación no fotoquímica de la energía ante condiciones de luz desfavorables. Las diferencias en la disipación de energía deben ser más evidentes en plántulas que en adultos debido a que las condiciones de luz y temperatura de sus ambientes son más contrastantes en este estado. La eficiencia fotoquímica máxima de las especies fluctuó entre 
0.70-083. La eficiencia fotoquímica efectiva, el amortiguamiento fotoquímico y la tasa de transporte de electrones fue mayor en plántulas de E. coccineum que en las de L. ferruginea. Los parámetros energéticos de amortiguamiento fotoquímico fueron mayores en adultos que en plántulas, pero a menudo similar entre los períodos del día, estaciones, especies y estados de desarrollo, con excepción de menores valores en las plántulas de E. coccineum en verano. Plántulas y adultos presentaron un mayor pool de xantofilas al mediodía en verano que en invierno, mientras que el pool de anteraxantina + zeaxantina fue siempre mayor al mediodía. Luteína experimentó el mayor incremento durante el verano. Plántulas y adultos de E. coccineum mantuvieron una alta fotosíntesis, una mayor proporción de centros abiertos y mayor ETR que la especie tolerante a la sombra. Se concluyó que la especie intolerante a la sombra, E. coccineum, fue capaz de utilizar más de la energía absorbida en la fotosíntesis a través de su ciclo de vida que la especies tolerante. Estas diferencias son consistentes con el carácter pionero, mayor tasa de crecimiento y más amplia distribución altitudinal y latitudinal de E. coccineum con respecto a L.ferruginea.

Palabras clave: ciclo de las xantófilas, fluorescencia de la clorofila, fotosíntesis, lutein, pigmentos fotoprotectores.

\section{INTRODUCTION}

Species of the family Proteaceae are frequent components of the temperate rain forest in South Central Chile (Weinberger 1974, Alberdi $\&$ Donoso 2004). The climatic and ecological requirements, as well the geographical distribution of the Chilean Proteaceae have been reported by Weinberger (1974). Among the Proteaceae, Embothrium coccineum J.R. et G. Forster (Notro, Ciruelillo) and Lomatia ferruginea (Cav.) R. Br. (Romerillo, Fuinque) have the widest and more austral distribution among Chilean Proteaceae (around $35^{\circ}$ to $56^{\circ} \mathrm{S}$ and $35^{\circ}$ to $52^{\circ} \mathrm{S}$, respectively). E. coccineum has an important physiognomic role in secondary communities. The light demands of these species are quite different. While $E$. coccineum is shade-intolerant, L. ferruginea is shade-tolerant (Weinberger 1974). Additionally, E. coccineum can also be a pioneer in lahares (layers of volcanic scoria subjected to high radiation and low night temperatures) (McQueen 1977, Alberdi \& Donoso 2004). Contrarily, L. ferruginea regenerates in the forest understory under very humid conditions.

Plants growing in exposed sites often experience an imbalance between light absorption and photosynthetic light utilization. The absorption of excessive light has the potential to lead to photooxidative damage (Logan et al. 1998), which can result in decreased photochemical efficiency of photosystem II (PSII) and photoinhibition (Demmig-Adams 2003, Valladares et al. 2005). Photosynthesis of tree seedlings grown in the forest understory can be affected by increased light levels (Kitao et al. 2000) or by sunflecks
(Tausz et al. 2005). Nevertheless, the optimal quantum yield already decreases due photoprotective down-regulation and not only by photodamage (Demmig-Adams 2003). Damage can be shown only if photosynthesis does not recover until evening, which is denominated chronic photoinhibition (Niyogy 1999). Excess energy can be harmlessly dissipated as thermal energy, thus limiting the production of reactive oxygen species (Demmig-Adams \& Adams 1992, Adams et al. 2002).

In addition to light, other environmental stresses, such as low temperature, water deficit or salinity stress can induce photoinhibition in plants (Björkman \& Powles 1984, DemmigAdams \& Adams 1992). In these cases, negative effects on the photosynthetic apparatus can occur at low light intensities (Demmig-Adams \& Adams 1992). It is accepted that the photoinhibitory responses are due principally to direct effects of the stress factor which can be well expressed by decreases of maximal quantum yield of fluorescence (Fv/Fm) (Demmig-Adams \& Adams 1992, Demmig-Adams \& Adams 1996, Adams et al. 2002). For example, in winter, when low temperatures limit photosynthetic carbon fixation the normal dissipation of excitation energy through photosynthesis is largely prevented by decreasing chlorophyll (Chl) content (Adams \& Barker 1998, Adams et al. 2004, Gilmore \& Ball 2000, Savitch et al. 2002) and by increasing thermal dissipation of the excess energy by the xanthophyll cycle (Adams \& Barker 1998, Niyogi 1999, Külheim et al. 2002). Although changes in zeaxanthin (Z) and antheraxanthin (A) have been repeatedly reported to be closely correlated with changes in the non-photochemical 
quenching (NPQ), which is a measure of energy dissipation for plants exposed to high light (Demmig-Adams \& Adams 1996), it has been suggested that this relation fails in some plants (Johnson et al. 1993). The xanthophyll lutein (Lut) and its epo-oxidation may also affect the level of thermal dissipation, especially in shade tolerant or shade-semi intolerant species (Matsubara et al. 2008). Other plants can maintain high rates of photosynthesis and the activity of other photochemical processes which serve as electron sinks reducing potentially damaging excess energy (Savitch et al. 2002, PérezTorres et al. 2006). In the case of short wavelengths (e.g. UV-B), the damage to photosynthetic targets can be severe. These relatively high energy photons may disrupt light energy transfer, electron transport of both photosystems and photosynthetic carbon reduction (Sullivan \& Rozema 1999).

Although studies about the physiology woody plants with different age are increasing, comparative studies on the seasonal variation in the energy quenching parameters of photosystem II (PSII) and photoprotective pigments in woody species at different developmental stages have not been fully characterized. To the best of our knowledge, most comparative changes on the photochemical energy quenching mechanisms of PSII and xanthophyll cycle pigments in woody and herbaceous species have been done in leaves at different ontogenetic stage, but not comparing individuals at different developmental stages (Yoo et al. 2003).

In this paper, we studied the seasonal variation in the energy quenching parameters of photosystem II (PSII) and photoprotective pigments in seedlings and adults of shade tolerant and intolerant species of Proteaceae $(L$. ferruginea and E. coccineum, respectively) from the Chilean temperate rainforest. We postulate that under light stress photochemical energy driven processes are favored in shade intolerant species while non-photochemical energy dissipation is the main strategy of shade tolerant species. Moreover, the shade tolerant species show lower seasonal variations in these parameters that the shade intolerant species. This difference in energy dissipation should be more evident in seedlings than adults as the effects of contrasting light environments and temperatures are more accentuated at this stage. The photoprotective strategies used by these species are discussed and related to the light conditions of their biotopes.

\section{METHODS}

\section{Study area and plant material}

This study was performed in a forest stand in Parque Katalapi, Pichiquillaipe, $10^{\text {th }}$ Region, in South-Central Chile $\left(41^{\circ} 31^{\prime} \mathrm{S}, 72^{\circ} 45^{\prime} \mathrm{W}\right)$, where the two Proteaceae grow naturally. The climate of this area is temperate and strongly humid with oceanic influence (Reyes-Díaz et al. 2005, Zúñiga et al. 2006). Seedlings (2-3 year old plants) and adults (reproductive plants) of these species were considered in this study. This work was conducted in winter (July) 2005 and summer (January) 2006, at midday, on clear days and predawn. Five individuals of each species and developmental stages were selected for repeated measurements of fluorescence parameters and net photosynthesis. Fully developed leaves from the leaf cohort from the spring 2004 were used. In adults, leaves were taken at similar heights and NE exposure. Climatic parameters were controlled with a Licor data logger (LI-1400) equipped with sensors for air temperature and relative humidity (LI 1400-104), and rain (LI 1400-106). Photosynthetic active radiation (PAR) $\left(\mu \mathrm{mol} \mathrm{m} \mathrm{m}^{-2} \mathrm{~s}^{-1}\right)$ was controlled in the microhabitats of the selected seedlings and adult plants at each season at midday (solar time) with a Li-Cor LI-189 digital quantum radiometer/photometer fitted with a quantum sensor (LI-190SA). At least 15 measurements were made at the top of the seedlings and above the twigs of adults during this time, without exclusion of shade and reflectance from other leaves. PAR measurements at open field were also made. With these data, the light environments for both species (as percentage of the light at the open field) were characterized.

\section{Net photosynthesis}

Light response curves of net photosynthesis of attached leaves were made using an infrared gas analyzer (IRGA; Ciras-1, PP system; Hitchin, UK). External air was scrubbed with 
$\mathrm{CO}_{2}$ and mixed with a supply of pure $\mathrm{CO}_{2}$ to reach a reference concentration of $360 \mathrm{ppm}$, with a flow rate of $200 \mathrm{~mL} \mathrm{~min}^{-1}$ and $80 \%$ external relative humidity. The relative humidity value is representative of the humidity at the study site, as indicated by the measurements with the Licor data logger (LI1400). The light response curves of photosynthesis were obtained by 17 irradiance values over a range between 0 and $2000 \mu \mathrm{mol}$ $\mathrm{m}^{-2} \mathrm{~s}^{-1}$ given by the PLC6(U) light unit, PPsystems Hertfordshire, UK.

\section{Chlorophyll fluorescence measurements}

In situ measurements of chlorophyll fluorescence of PSII were made with a portable pulse-amplitude modulated fluorometer (FMSII, Hansatech Instruments Ltd., Norfolk, UK). Comparable leaves as those used for IRGA determinations were selected for the fluorescence analyses. The protocol of ReyesDíaz et al. (2005) was followed. Fluorescence of attached leaves was measured after dark adaptation for $30 \mathrm{~min}$ (to obtain open centers) with leaf-clips provided by a mobile shutter plate. Then the fiber-optic and its fiber-optic adapter were fixed to a ring located over the clip at about $10 \mathrm{~mm}$ from the sample and light pulses were applied. Basal fluorescence (Fo) was determined by applying a weak-modulated light $\left(0.4 \mu \mathrm{mol}\right.$ photons $\left.\mathrm{m}^{-2} \mathrm{~s}^{-1}\right)$ and maximal fluorescence $(\mathrm{Fm})$ was induced by a short pulse $(0.8 \mathrm{~s})$ of saturating light $(9000 \mu \mathrm{mol}$ photons $\left.\mathrm{m}^{-2} \mathrm{~s}^{-1}\right)$. After $10 \mathrm{~s}$, actinic light $(500 \mu \mathrm{mol}$ photons $\mathrm{m}^{-2} \mathrm{~s}^{-1}$ ) was turned on to obtain fluorescence parameters during steady-state photosynthesis. This irradiance was selected based on previous determinations of the light saturating curve for PSII in both species (not shown). The use of similar irradiance in both species allows a more standardized comparison than variable natural light. Thus, the differences during long-term exposition to the local irradiance climate will be better represented in the species than the episodic short term irradiance. Definitions of fluorescence parameters ( $\mathrm{qP}, \mathrm{NPQ}, \mathrm{Fv} / \mathrm{Fm}$ and $\Phi P S I I$ were used as described by Maxwell \& Johnson (2000). The maximum quantum yield of fluorescence $(\mathrm{Fv} / \mathrm{Fm})$ is defined as the ratio variable fluorescence/maximal fluorescence and represents the maximal photochemical efficiency of PSII when all the centres are open (dark conditions) and the effective quantum yield $(\Phi P S I I=(F m '-F s) / F m ')$ represents the photochemical efficiency under light conditions, that is when photosynthesis occurs (Genty et al. 1989).

Electron transport rate was estimated as: ETR $=$ PAR $\times 0.5 \times$ PPSII $\times 0.84$ following the indications provided by the $\Phi$ MSII user's manual (Hansatech, UK). This parameter is also denominated relative electron transport (rETR, Schreiber et al. 1994). PAR used was $500 \mu \mathrm{mol}$ photons $\mathrm{m}^{-2} \mathrm{~s}^{-1}$. Photochemical quenching $(\mathrm{qP})$ was calculated as: $\mathrm{qP}=(\mathrm{Fm}$ ' Fs)/(Fm' - Fo'), with Fm' being the maximal fluorescence in light adapted leaves, and Fs the steady state fluorescence yield. Nonphotochemical quenching (NPQ) was determined at midday and calculated as: $\mathrm{NPQ}=$ (Fm - Fm')/Fm' (Bilger \& Björkman 1990, Maxwell \& Johnson 2000). When steady state fluorescence was reached, saturating pulses were applied to obtain Fm'.

\section{Pigment determinations}

After fluorescence measurements, the same leaves were detached and immediately placed in liquid nitrogen and kept frozen at $-80{ }^{\circ} \mathrm{C}$ until pigments analyses. Pigments were extracted with $100(\mathrm{v} / \mathrm{v})$ HPLC grade acetone at $4{ }^{\circ} \mathrm{C}$ under a green safelight. After centrifugation $(5.000 \mathrm{~g})$ at $0{ }^{\circ} \mathrm{C}$ for $3 \mathrm{~min}$, the supernatant was filtered through a $0.22-\mu \mathrm{m}$ syringe filter and samples were stored at $-80{ }^{\circ} \mathrm{C}$ until analysis. One aliquot was used for spectrophotometric determinations of chlorophylls a ( $\mathrm{Chl}$ a) and $\mathrm{b},(\mathrm{Chl} \mathrm{b})$ and total carotenoids (with a Metertek SP 850 spectrophotometer, Taipei, Taiwan), using the extinction coefficients and equations determined by Lichtenthaler \& Wellburn (1983). A second aliquot was used for xanthophyll analyses. They were separated and quantified by HPLC (Hewlett Packard 1100, Agilent Technologies Inc., San Jose, CA, USA) according to the method described by Gilmore \& Yamamoto (1991) with minor modifications (Zúñiga et al. 2006). $50 \mu \mathrm{L}$ of the extract were injected in a Zorbax $\mathrm{Rx}-\mathrm{C} 18$ reversed phase HPLC column $(250 \times 4.6 \mathrm{~mm}$ ID, $5 \mu \mathrm{m}$ particle size) protected by a Zorbax Rx-C18 guard column (12.5 x $4.6 \mathrm{~mm}$ ID, $5 \mu \mathrm{m})$. For 
separation, a mobile phase consisting of two components was used: solvent A, acetonitrile:methanol:buffer Tris- $\mathrm{HCl} 0.1 \mathrm{M} \mathrm{pH}$ $8.0(72: 8: 3 \mathrm{v} / \mathrm{v})$ and solvent $\mathrm{B}$, methanol:ethyl acetate $(68: 32 \mathrm{v} / \mathrm{v})$. Pigments were eluted using a gradient of solvent $\mathrm{A}$, running isocratically for 6 minutes, followed by 10 minutes of a linear gradient up to $100 \%$ of the solvent mixture $\mathrm{B}$ and 4 minutes of isocratic mixture of the last solvent. The retention times and response factors of pigments of violaxanthin $(\mathrm{V})$, antheraxanthin (A), zeaxanthin (Z) were measured by using standards provided by DHI Water and Environment, Copenhagen, DK. Lutein (Lut) standards were obtained from Sigma, St Louis, MO, USA. All standards were in ethanol. Concentrations of xanthophylls were expressed on $\mathrm{Chl} \mathrm{a}+\mathrm{b}$ basis. Epoxidation state (EPS) of the xanthophyll pool was calculated as: $\mathrm{EPS}=(\mathrm{V}+0.5 \mathrm{~A}) /(\mathrm{V}+\mathrm{A}+\mathrm{Z})$.

\section{Statistical analyses}

Determinations are based on 5 replicates, corresponding to 5 individuals in each species $(n=5)$. All data passed the normality and equal variance tests after the Kolmogorov-Smirnov test. The data were analyzed by two-way repeated measures analyses of variance (ANOVA) to test the effects of season and development stage on pigments, photosynthesis rate, and chlorophyll fluorescence. A Tukey test was used to identify those means with significant differences. The software Sigma Stat 2.0 software (SPSS ${ }^{\circledR}$ Inc., Chicago, IL, USA) was used for both analyses. Differences between the values were determined at $\mathrm{P} \leq$ 0.05 . Spearman correlations $\left(\mathrm{r}_{\mathrm{s}}\right)$ were made to establish relations between some parameters with the same software mentioned above.

\section{RESULTS}

\section{Environmental conditions in the study site}

Rainfall during the austral winter reached 731 $\mathrm{mm}$ in June, July and August, while in summer values decreased to $278 \mathrm{~mm}$ in December, January and February (Fig. 1A). Maximum air temperatures in summer were close to $30{ }^{\circ} \mathrm{C}$, while in winter minimum values were close to $2{ }^{\circ} \mathrm{C}$ (Fig. 1B).
Irradiance at full light between winter and summer were approximately $30 \%$ less in winter than in summer (Table 1). Seedlings of E. coccineum received 73-74\% irradiance with respect to the light in the open field in winter and summer, respectively, whereas adults of this species received 93-94\%. For L. ferrugina seedlings, irradiance relative to those of open field, was around $10 \%$ in both seasons. In the case of adults, values were $46 \%$ in winter and $39 \%$ in summer. The irradiance over seedlings was lower than in adults due to shading and probably by different reflectance. Relative humidity (RH) at midday was about $75 \%$ in summer and $80 \%$ in winter. Temperatures of air surrounding leaves were $3{ }^{\circ} \mathrm{C}$ to $6{ }^{\circ} \mathrm{C}$ in winter, whereas in summer they peaked up 12 ${ }^{\circ} \mathrm{C}$ for seedlings and $16{ }^{\circ} \mathrm{C}$ for adults.

\section{Net photosynthesis}

The photosynthetic rate was higher in summer than in winter in both developmental stages, with the exception of seedlings from the shade tolerant plants (Fig. 2). The highest photosynthetic rates were found in seedlings and adults of $E$. coccineum $(\mathrm{P} \leq 0.05)$. Light saturation points for photosynthesis were around $500 \pm 64 \mu \mathrm{mol}$ photons $\mathrm{m}^{-2} \mathrm{~s}^{-1}$ for seedlings and adults of E. coccineum and $250 \pm$ 31 and $480 \pm 93 \mu$ mol photons $\mathrm{m}^{-2} \mathrm{~s}^{-1}$ for seedlings and adults of L. ferruginea, respectively (Fig. 2).

\section{Photochemical efficiency of the PSII}

Maximum quantum yield (Fv/Fm) of $L$. ferruginea did not vary with developmental stage, season or daily period, while seedlings and adults of the shade-intolerant E. coccineum showed lower values of $\mathrm{Fv} / \mathrm{Fm}$ in winter than in summer at predawn and midday $(\mathrm{P} \leq 0.05)$ (Table 2). In winter, seedlings of both species generally showed lower effective quantum yield (ФPSII), photochemical quenching (qP) and electron transport (ETR) than in summer (P $\leq 0.05$ ) (Table 2). These photochemical parameters were statistically significant higher $(\mathrm{P} \leq 0.05)$ at midday than predawn in both development stages, especially in the heliophyte E. coccineum. In this species, the photochemical parameters of seedlings and adults showed higher values than the shade 

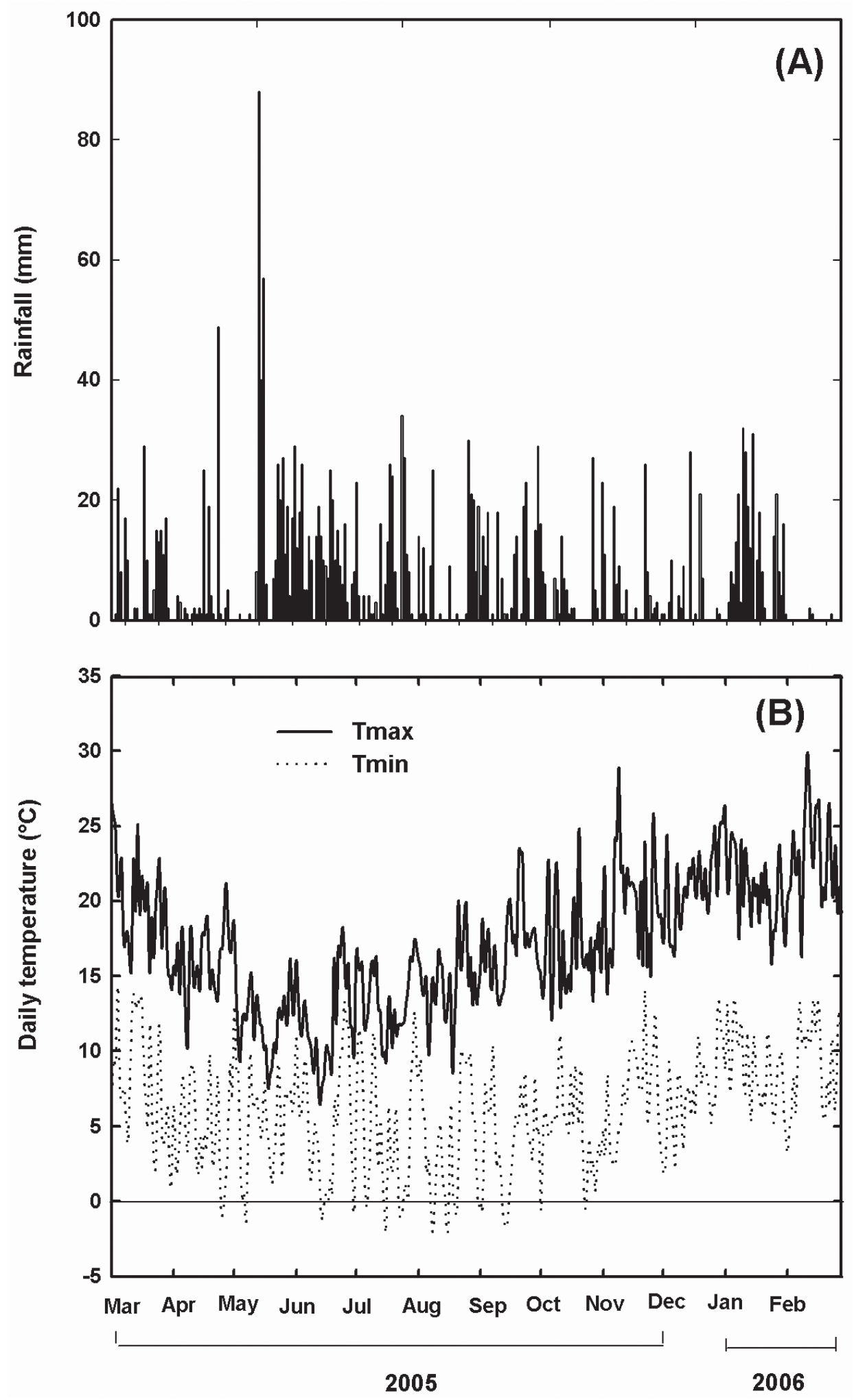

Fig. 1: Seasonal course of rainfall (A) and maximum and minimum temperatures in the study site (B) from March 2005 to February 2006.

Curso estacional de la pluviosidad (A) y temperaturas máximas y mínimas en el sitio de estudio (B) desde marzo de 2005 a febrero de 2006 . 
tolerant species. Similar NPQ values in seedlings of the two species were found in winter, whereas in summer, at the same daily period, a higher NPQ was found in the shade tolerant species L. ferruginea $(\mathrm{P} \leq 0.05)$ compared to the heliophyte E. coccineum (Fig. $3)$. Differences in NPQ were found only in winter in adults with L. ferruginea showing the highest values $(\mathrm{P} \leq 0.05)$.

Pigments of the xanthophylls cycle and epoxidation state

Seasonal differences between the xanthophyll pools (VAZ) at both developmental stages were found at both daily periods (Table 3). Violaxanthin (V) decreased from predawn to midday in the two seasons in seedlings and adults of both species, with the exception of adults of $E$. coccineum in summer. Antheraxanthin + Zeaxanthin $(\mathrm{A}+\mathrm{Z})$ contents

\section{TABLE}

Light irradiance conditions in seedlings and adults of the investigated Proteaceae in the study site. Measurements were made at midday in winter and summer. Irradiance values are means of at least 15 measurements over different leaves of each species. The mean irradiance at full light (open field) was 1998 $\mu \mathrm{mol} \mathrm{m} \mathrm{m}^{-2} \mathrm{~s}^{-1}$ in summer and $1490 \mu \mathrm{mol} \mathrm{m}^{-2} \mathrm{~s}^{-1}$ in winter. The percentages of incident light irradiance $(\%)$ above the plants with respect to full light are shown in parenthesis.

Condiciones de irradiancia de luz en plántulas y adultos de las Proteáceas investigadas en el sitio de estudio. Las mediciones fueron realizadas al mediodía en invierno y verano. Los valores de irradiancia corresponden a promedios de al menos de 15 mediciones realizadas sobre las hojas de cada especie. El promedio de irradiancia a plena luz (campo abierto) fue de $1998 \mu \mathrm{mol} \mathrm{m}^{-2} \mathrm{~s}^{-1}$ en verano y $1490 \mu \mathrm{mol} \mathrm{m}^{-2} \mathrm{~s}^{-1}$ en invierno. Los porcentajes de irradiancia incidente sobre las plantas $(\%)$ con respecto a la luz en campo abierto se presentan en paréntesis.

\begin{tabular}{lccc}
\hline Species & $\begin{array}{c}\text { Developmental } \\
\text { stage }\end{array}$ & \multicolumn{2}{c}{$\begin{array}{c}\text { Light Irradiance } \\
\left(\mu \mathrm{mol} \mathrm{m}^{-2} \mathrm{~s}^{-1}\right)\end{array}$} \\
\cline { 3 - 4 } & & Winter & Summer \\
\hline E. coccineum & Seedlings & $1092(73)$ & $1472(74)$ \\
& Adults & $1380(93)$ & $1885(94)$ \\
L.ferruginea & Seedlings & $183(12)$ & $194(10)$ \\
& Adults & $680(46)$ & $778(39)$ \\
\hline
\end{tabular}

increased from predawn to midday in seedlings in winter and summer. The same pattern was observed in adults, with the exception of the shade tolerant $L$. ferruginea in winter and the heliophyte E. coccineum in summer. In summer, the VAZ pool increased from predawn to midday in seedlings and adults of the two species. The reverse pattern was observed in winter, when VAZ values decreased (Table 3 ). The highest VAZ pools were found in adults of L. ferruginea at midday in summer $(\mathrm{P} \leq 0.05)$, and in winter, in both development stages of $E$. coccineum at predawn $(\mathrm{P} \leq 0.05)$. Lutein values were much lower in winter than in summer (Table 3). Lutein contents decreased at midday in summer compared to predawn in seedlings. In adults, little increases were found at midday with respect to dawn, with the exception of the shade tolerant species that increased its lutein content by $41 \%$ (Table 3 ).

Daily differences in the EPS were found in seedlings and adults of the two species with higher values at predawn than midday in both seasons $(\mathrm{P} \leq 0.05)$. In adults of E. coccineum in summer, no differences between the daily periods were found (Table 3 ). In the case of developmental stages, differences were found in winter at midday in the two species, showing adults of $L$. ferruginea a lower EPS than seedlings $(\mathrm{P} \leq 0.05)$. In contrast, adults of $E$. coccineum had the highest EPS at predawn $(\mathrm{P} \leq$ 0.05). In summer, the highest EPS values at midday were determined in adults of $E$. coccineum.

\section{Chlorophyll and total carotenoid contents}

Seedlings of L. ferruginea measured at midday had higher $\mathrm{Chl} \mathrm{a}+\mathrm{b}$ contents than $E$. coccineum in winter and summer $(\mathrm{P} \leq 0.05)$ (Table 4$)$. Small or non significant differences were found in $\mathrm{Chl} \mathrm{a}+\mathrm{b}$ contents in adults. Differences between the daily periods in pigments were found only in winter in seedlings of $E$. coccineum with higher values at predawn than midday $(\mathrm{P} \leq 0.05)$. In winter, increased $\mathrm{Chl} \mathrm{a} / \mathrm{b}$ ratios were determined at midday in seedlings of both species. This ratio was frequently higher in the heliophyte than in the umbrophyllous species, irrespective of the daily period and development stage $(\mathrm{P} \leq 0.05)$. The Car/Chl ratio did not show daily changes. Small differences in Car/Chl between the 
species were found in seedlings. In both species and developmental stages $\mathrm{Car} / \mathrm{Chl}$ ratios were higher in summer than in winter (Table 4)

\section{DISCUSSION}

There are numerous reports focused on photoinhibition of photosynthesis in evergreen plants that experience chilling and freezing temperatures during winter (Ottander et al. 1995, Ivanov et al. 2001, García-Plazaola et al. 2003). Species of a moist tropical forest growing in a natural gap during the dry season suffer midday photoinhibition, which is reversible during the evening (Krause and Winter 1996). These authors concluded that photoinhibition and recovery of photosynthesis in these species reflect a regulatory mechanism of thermal energy dissipation that allows these plants to cope with periods of high light in tropical forest gaps. Our study is one of the first field studies on photoprotection performed in the temperate rainforest of the Southern Hemisphere examining plants at different ontogenetic stages. It was demonstrated that in summer, the optimal photochemical efficiency $(\mathrm{Fv} / \mathrm{Fm})$ was within the physiological ranges for healthy leaves (0.80-0.84) (Björkman \& Demmig 1987) at both developmental stages. In winter, seedlings and adults of E. coccineum showed statistically significant lower $\sim 14 \%$ (P $\leq 0.05) \mathrm{Fv} / \mathrm{Fm}$ values than in summer. Thus, $\mathrm{Fv} / \mathrm{Fm}$ of seedlings and adults of the shadeintolerant $E$. coccineum seems to be more perturbed during the coldest season. This response may be explained by a combination of low temperature and moderate light as

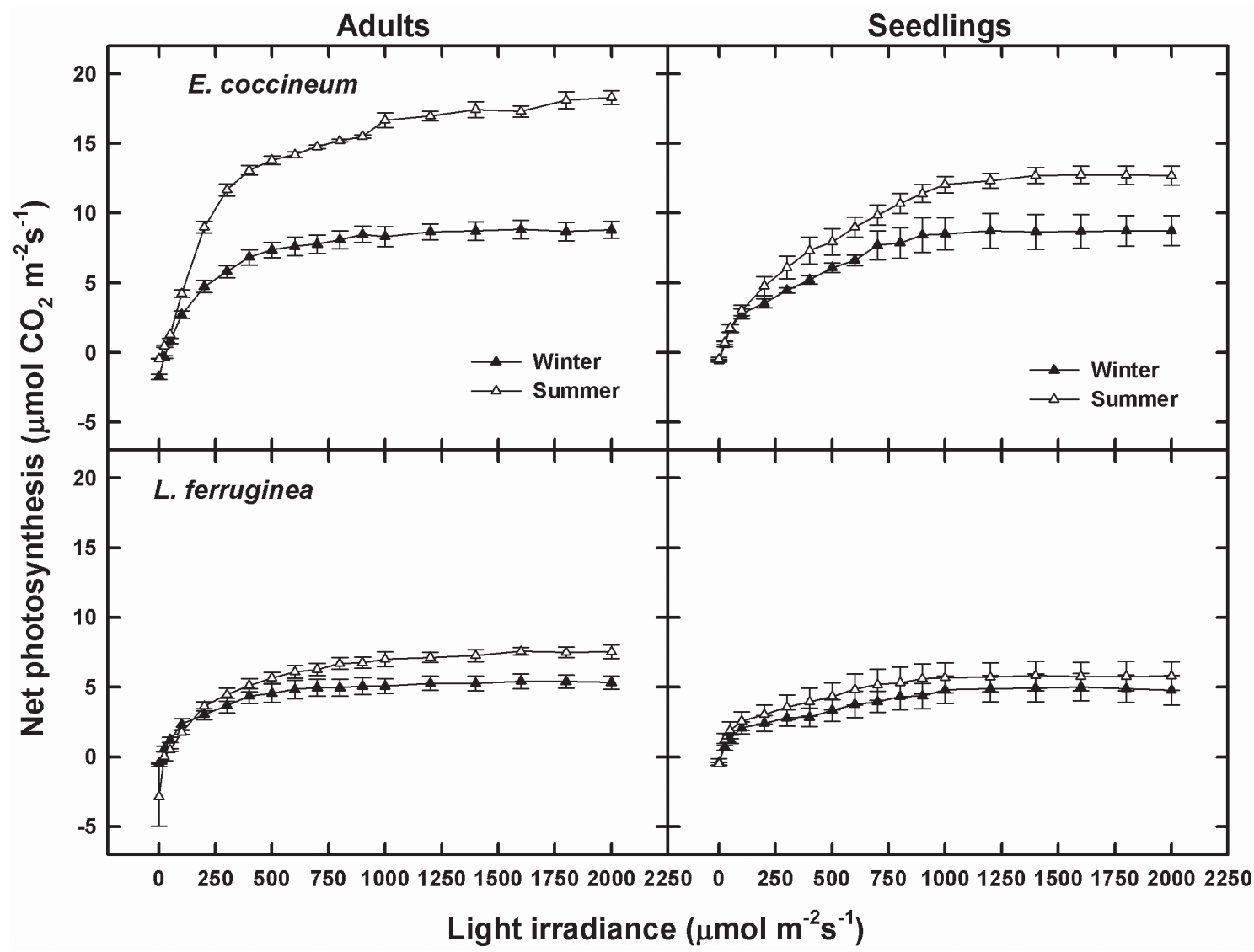

Fig. 2: Seasonal changes in light response curves of net photosynthesis of Proteaceae from the temperate Chilean rain forest at two different developmental stages. Values are means \pm SE of 5 replicates.

Cambios estacionales en las curvas de respuesta a la luz de la fotosíntesis neta en Proteáceas del bosque templado chileno en dos estados de desarrollo. Valores son promedios \pm ES de 5 réplicas. 


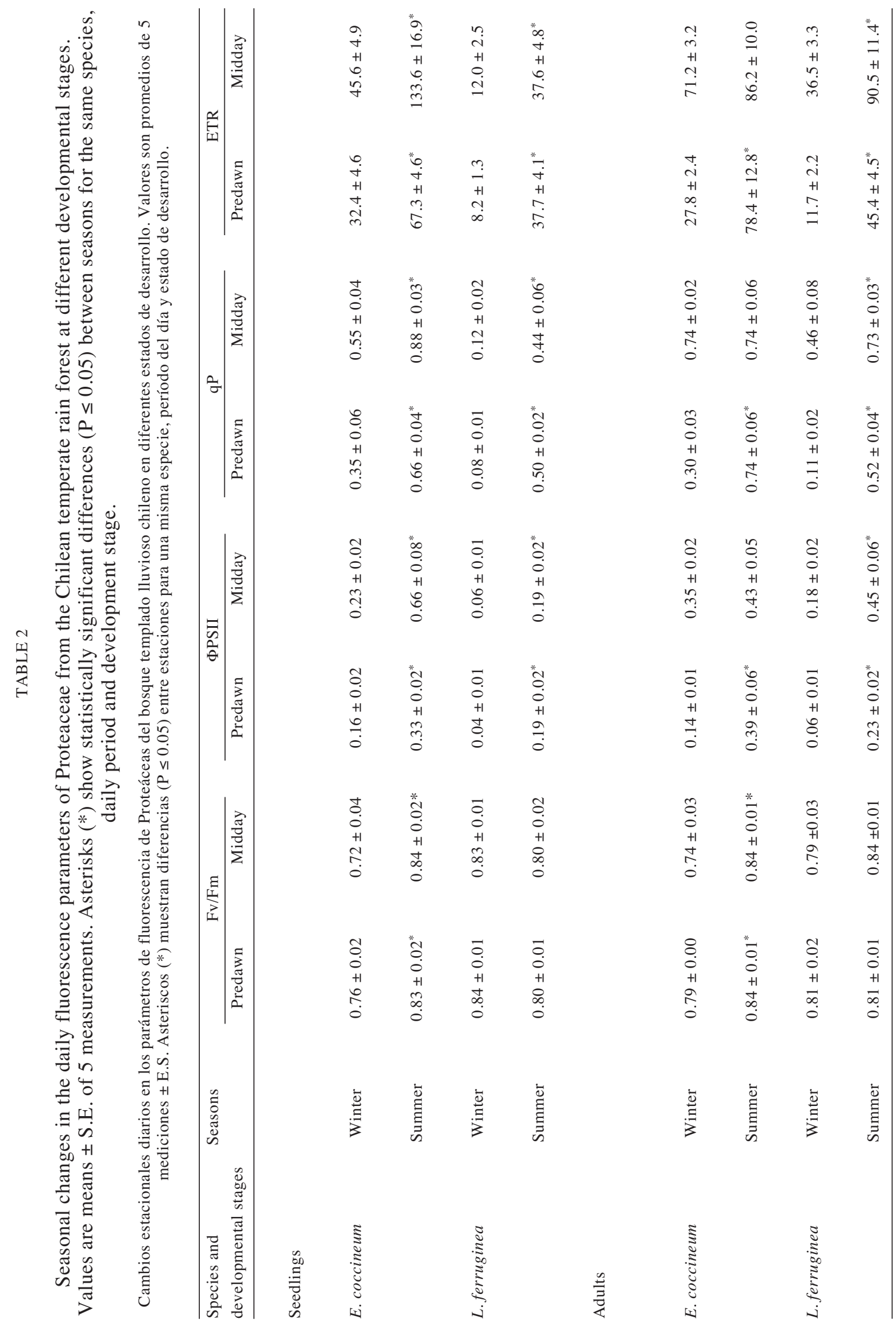




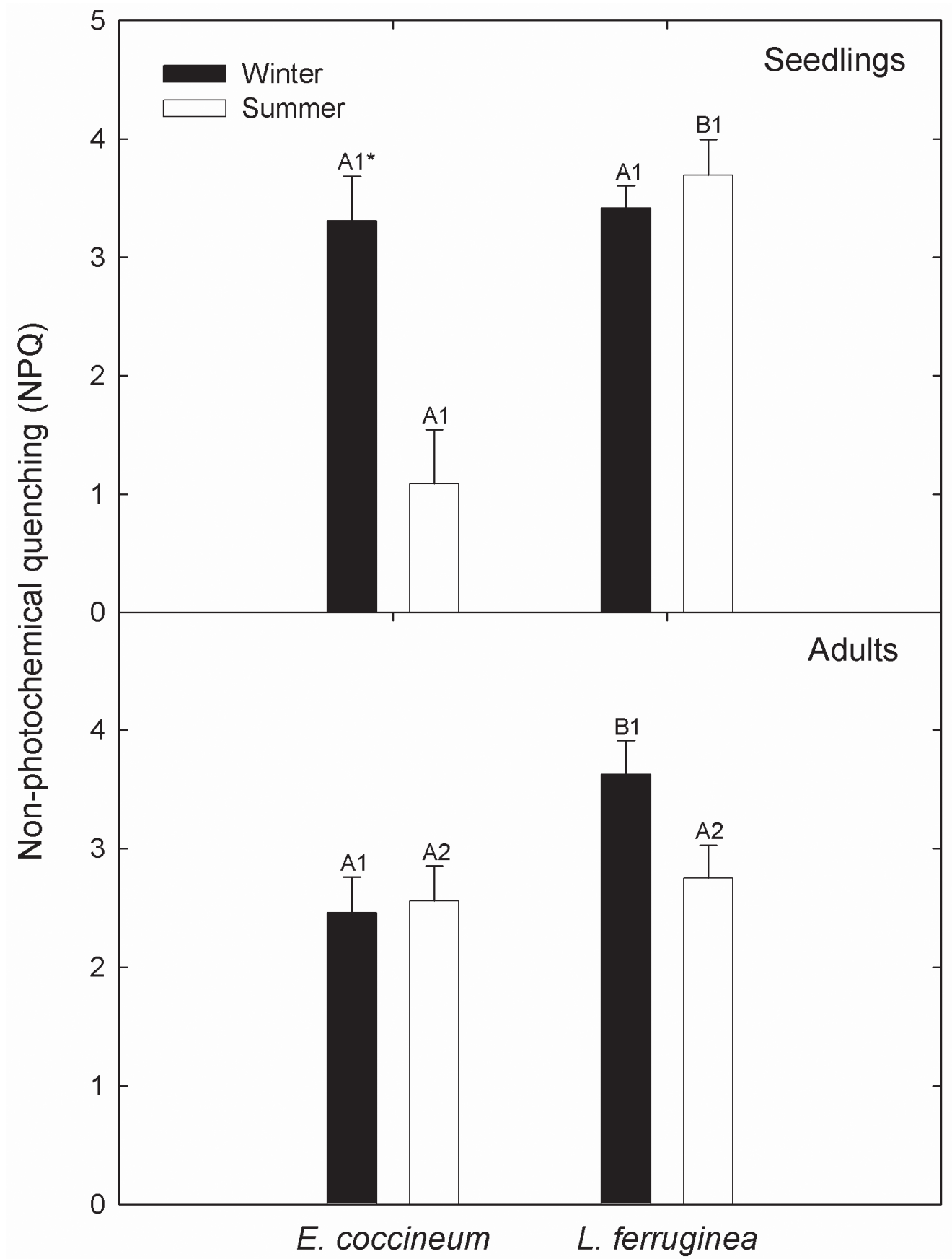

Fig. 3: Seasonal and daily changes in non-photochemical quenching (NPQ) of Proteaceae from the temperate Chilean rain forest at two different developmental stages. Values are means \pm SE of 5 replicates. Different upper case letters denote statistically significant differences $(\mathrm{P} \leq 0.05)$ between species for the same season and developmental stage. Different numbers indicate statistically significant differences $(\mathrm{P} \leq 0.05)$ between developmental stages for the same species and season. Asterisks $(*)$ show statistically significant differences $(\mathrm{P} \leq 0.05)$ between seasons for the same species and developmental stage.

Cambios estacionales y diarios en el apagamiento no fotoquímico (NPQ) de Proteáceas del bosque templado chileno en dos estados de desarrollo. Valores son promedios de 5 réplicas \pm ES. Letras mayúsculas diferentes muestran diferencias $(\mathrm{P} \leq$ $0.05)$ entre especies en la misma estación y estados de desarrollo. Números diferentes indican diferencias estadísticamente significativas $(\mathrm{P} \leq 0.05)$ entre los estados de desarrollo para cada especie y estación. Asteriscos $(*)$ señalan diferencias estadísticamente significativas $(\mathrm{P} \leq 0.05)$ entre estaciones para la misma especie y estado de desarrollo. 


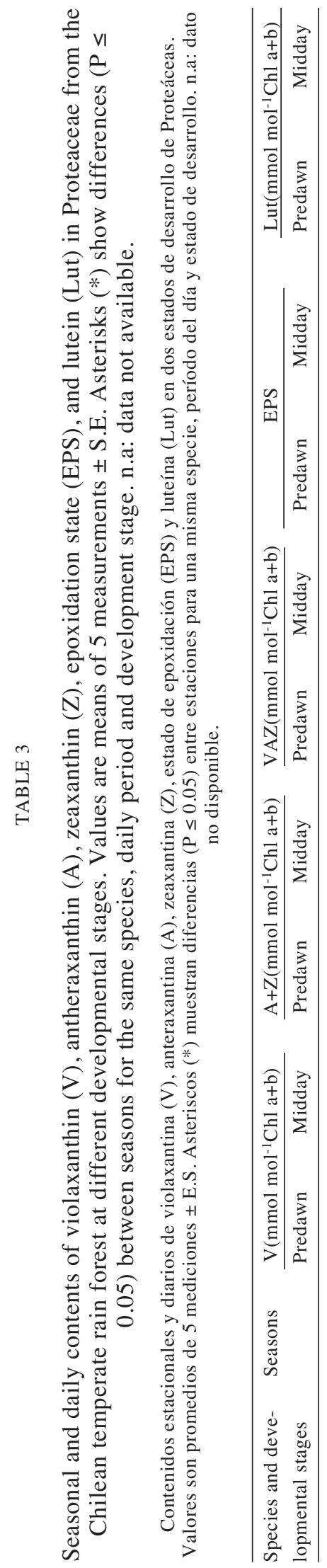

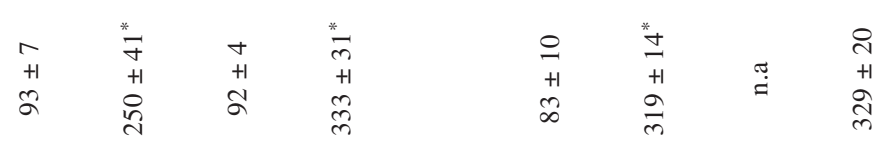

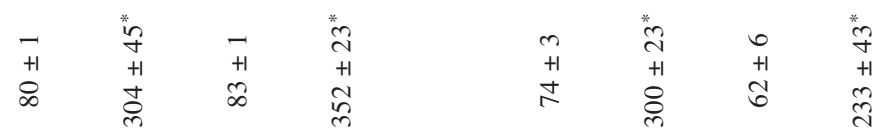

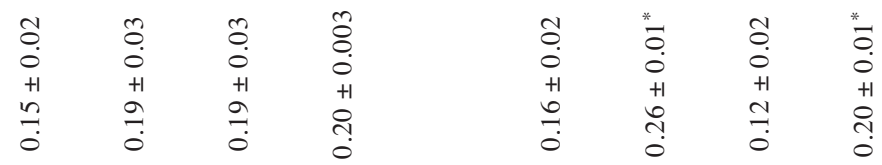

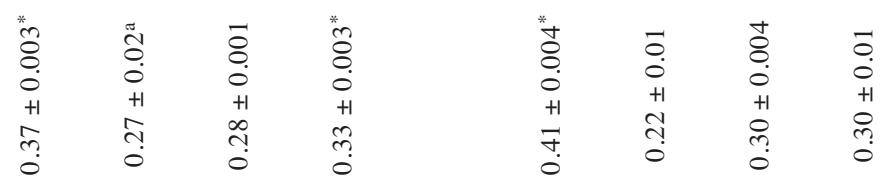

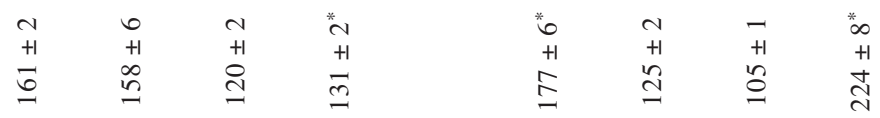

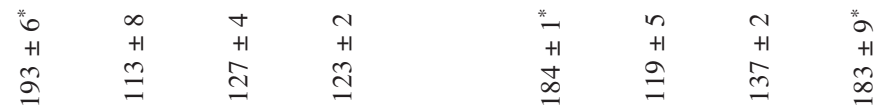

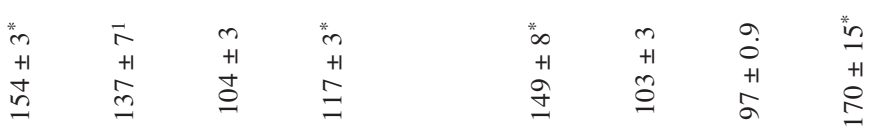

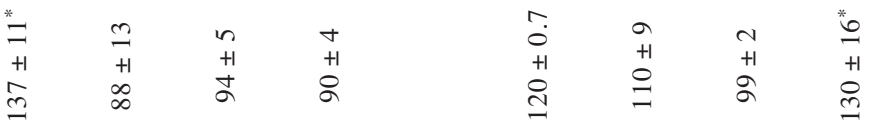

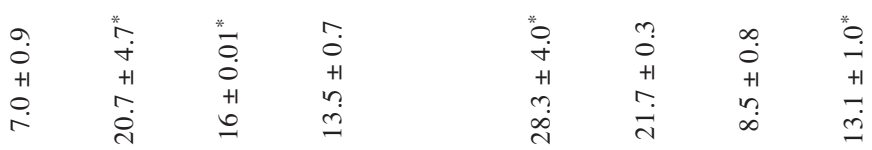

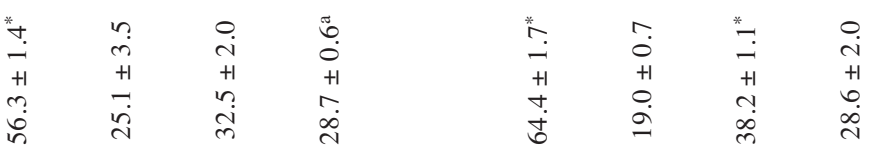

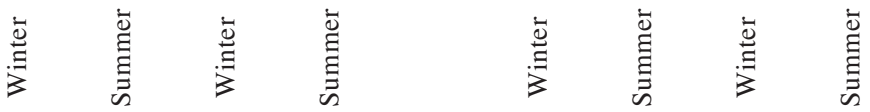


TABLE 4

Seasonal and daily contents of total chlorophylls $(\mathrm{Chl} \mathrm{a+b})$, cholorophyll ratio $(\mathrm{Chl} \mathrm{a} / \mathrm{b})$ and total carotenoids/Chl a+b ratio $(\mathrm{Car} / \mathrm{Chl})$ in two Proteaceae from the Chilean temperate rain forest at different developmental stages. Values are means of 5 measurements \pm S.EAsterisks $(*)$ show differences $(\mathrm{P} \leq 0.05)$ between seasons for the same species, daily period and development stage.

Contenidos estacionales y diarios en clorofila total $(\mathrm{Chl} \mathrm{a}+\mathrm{b})$, radio de clorofila $(\mathrm{Chl} \mathrm{a} / \mathrm{b})$ y carotenoids totales/carotenoids/ $\mathrm{Chl} \mathrm{a}+\mathrm{b}$ radio $(\mathrm{Car} / \mathrm{Chl})$ en dos Proteáceas. Valores son promedios de 5 mediciones \pm E.S. Asteriscos $(*)$ muestran diferencias $(\mathrm{P} \leq 0.05)$ entre estaciones para la misma especie, período del día y estado de desarrollo.

\begin{tabular}{|c|c|c|c|c|c|c|c|}
\hline \multirow{2}{*}{$\begin{array}{l}\text { Species and } \\
\text { development } \\
\text { stages }\end{array}$} & \multirow[t]{2}{*}{ Seasons } & \multicolumn{2}{|c|}{ Chl a+b (mg g-1 FW) } & \multicolumn{2}{|c|}{$\mathrm{Chl} \mathrm{a/b}$} & \multicolumn{2}{|c|}{ Car/Chl } \\
\hline & & Predawn & Midday & Predawn & Midday & Predawn & Midday \\
\hline \multicolumn{8}{|l|}{ Seedlings } \\
\hline \multirow[t]{2}{*}{ E. coccineum } & Winter & $1.46 \pm 0.09$ & $1.22 \pm 0.04$ & $3.35 \pm 0.21$ & $3.89 \pm 0.11$ & $0.23 \pm 0.01$ & $0.23 \pm 0.003$ \\
\hline & Summer & $1.65 \pm 0.30$ & $1.63 \pm 0.19^{*}$ & $3.12 \pm 0.24$ & $3.48 \pm 0.54$ & $0.28 \pm 0.02^{*}$ & $0.27 \pm 0.02^{*}$ \\
\hline \multirow[t]{2}{*}{ L. ferruginea } & Winter & $1.83 \pm 0.05$ & $1.88 \pm 0.03$ & $2.54 \pm 0.13$ & $2.79 \pm 0.04^{*}$ & $0.27 \pm 0.04^{1}$ & $0.26 \pm 0.03^{1}$ \\
\hline & Summer & $1.57 \pm 0.13$ & $2.10 \pm 0.25$ & $2.64 \pm 0.14$ & $2.52 \pm 0.07$ & $0.36 \pm 0.02^{*}$ & $0.35 \pm 0.03^{*}$ \\
\hline \multicolumn{8}{|l|}{ Adults } \\
\hline \multirow[t]{2}{*}{ E. coccineum } & Winter & $1.60 \pm 0.11$ & $1.47 \pm 0.01$ & $3.32 \pm 0.07$ & $3.49 \pm 0.08$ & $0.23 \pm 0.01$ & $0.23 \pm 0.01$ \\
\hline & Summer & $1.58 \pm 0.09$ & $1.46 \pm 0.11$ & $2.89 \pm 0.34$ & $3.16 \pm 0.38$ & $0.29 \pm 0.05^{*}$ & $0.25 \pm 0.02^{*}$ \\
\hline \multirow[t]{2}{*}{ L. ferruginea } & Winter & $1.56 \pm 0.04^{*}$ & $1.66 \pm 0.02$ & $2.65 \pm 0.12$ & $2.74 \pm 0.05$ & $0.21 \pm 0.01$ & $0.19 \pm 0.002$ \\
\hline & Summer & $1.15 \pm 0.11$ & $1.54 \pm 0.22$ & $2.75 \pm 0.27$ & $2.67 \pm 0.10$ & $0.40 \pm 0.05^{*}$ & $0.34 \pm 0.04^{*}$ \\
\hline
\end{tabular}

additional stress can exacerbate the detrimental effect of light (Bilger \& Björkmann 1990). This pattern is consistent with the semidecidous character of E. coccineum, but not in $L$. ferruginea (Weinberger 1974). Nonetheless, $\mathrm{Fv} / \mathrm{Fm}$ values of 0.70 are considered within the normal range for trees (Mohammed et al, 2003) and therefore it can not be interpreted as photodamage, but as a regulatory adjustment of PSII efficiency (Huner et al. 2002). In contrast, the evergreen Nothofagus dombeyi from the Chilean temperate rainforest showed a decrease in $\mathrm{Fv} / \mathrm{Fm}$ in summer at the highest irradiances (midday) (Zúñiga et al. 2006), but not in winter as was found in our study for L. ferruginea and E. coccineum. Because this decline was reversed in the afternoon in $N$. dombeyi, these authors suggested a photoprotective down regulation of the PSII mediated by $\mathrm{Z}$, thus preventing the damage of the photosynthetic system as reported by other authors (Adams \& Demmig-Adams 1994, Krause \& Winter 1996). In our case, there was only a small decrease in $\mathrm{Fv} / \mathrm{Fm}$ in seedlings and adults of E. coccineum in winter.
The lower NPQ (thermal energy dissipation) showed in seedlings of E. coccineum in summer at midday (Fig. 3) is concomitant with a higher DPSII, qP and ETR of this species (Table 2). Thus, in summer, E. coccineum showed a higher utilization of the absorbed energy in electron transport and therefore higher $\mathrm{CO}_{2}$ assimilation than L. ferruginea (Fig. 2). This supports well the pioneer and heliophyte features of E. coccineum (Weinberger 1974). In seedlings and adults of the investigated species, the midday NPQ was negatively correlated with ФPSII and $\mathrm{qP},\left(\mathrm{r}_{\mathrm{s}}=\right.$ $-0.9 \mathrm{P} \leq 0.05)$, as found in other plants (Demmig-Adams \& Adams 1996). On the other hand, NPQ was higher in winter than in summer in seedlings of E. coccineum and $L$. ferruginea concomitant with a lower photosynthesis, ФPSII, ETR and qP. According to Adams et al. (1995), NPQ reaches higher levels at temperatures that severely slow down photosynthesis rates. It is known that changes in NPQ are closely and directly correlated with changes in $\mathrm{A}+\mathrm{Z}$ in leaves exposed to high light (Bilger \& Björkman 1990, Gilmore \& 
Yamamoto 1993, Demmig-Adams \& Adams 1996, Stroch et al. 2008). It has also been suggested that the xanthophyll cycle can be unrelated to NPQ, because no direct quantitative relationships between $\mathrm{Z}$ or $\mathrm{A}+\mathrm{Z}$ levels and NPQ exist (Johnson et al. 1993). Our results did not support the first assumption because the investigated Proteaceae showed no correlation between NPQ and $\mathrm{A}+\mathrm{Z}\left(\mathrm{r}_{\mathrm{s}}=-0.28\right.$, $P>0.05)$. Therefore, it appears that the relation between NPQ and the increase in A+Z may not be common to all plants. The xanthophyll cycle facilitated energy dissipation is complex and variations of this process can be expected according to the different genetic and ecological context of different plants species (Demmig-Adams \& Adams 1992, 1996).

There appears to be a high proportion of nocturnal retention of $A+Z$ in these two Proteaceae, similar as has been found in $N$. nitida, a species from the Chilean temperate rainforest (Zúñiga et al. 2006). Sustained retention of large amounts of $A+Z$ appears to be a common response to low temperature stress under field conditions in plants (Adams \& Demmig-Adams 1994, Adams \& Barker 1998, Verhoeven et al. 1999). The deepoxidation of $\mathrm{V}$ to $\mathrm{A}$ and $\mathrm{Z}$ increases strongly in cold acclimated pine needles as reflected by decreasing values of the EPS (Savitch et al. 2002). Contrarily, we found higher or similar EPS in winter than in summer at both developmental stages. This suggests that under the relative milder winter temperature conditions of South- Central Chile with respect to the Northern Hemisphere, de-epoxidation of $\mathrm{V}$ to $\mathrm{A}+\mathrm{Z}$ is not enough to produce a strong decrease in EPS.

In this work, the daily changes in xanthophyll pigments seem to be more important than seasonal variation (winter compared to summer). Our results suggest a close relationship between irradiance and changes in xanthophylls pigments (DemmigAdams \& Adams 1996). This response has often been observed in a wide range of plant species growing in natural sunlight (DemmigAdams \& Adams 1992, 1996, Adams et al. 1999).

Another important photoprotective and accessory pigment is Lut (Matsubara et al. 2008). Our results showed that the higher concentration of this carotenoid occurred in summer, concomitant with a higher photosynthesis. This is different that found in plants of colder climates of the Northern Hemisphere, where accumulation of Lut occurs during cold acclimation in winter (Adams \& Demmig-Adams 1994, Verhoeven et al. 1999, Savitch et al. 2002). Interestingly, a progressively high Lut summer induction associated with an increase of the VAZ pool, reaching a peak during a heat wave, was recently reported for the Mediterranean evergreen Buxus sempervirens (Hormaetxe et al. 2007). From the comparison of these results with those of a non-stressful summer, these authors concluded that the summer increase in Lut of $B$. sempervirens was not strictly seasonal. In our study, lutein accumulated more in summer than in winter at both developmental stages, regardless of the species suggesting a general photoprotective role in Proteaceae. Lut accumulation is only related with a higher VAZ pool in adults of the shade-tolerant $L$. ferruginea. The higher Lut contents in summer could represent a specific adaptation to cope with the variable light environment (sun flecks in the case of the more umbrophyllous species and high light intensities at midday in the case of the heliophyte species), prevalent in the evergreen temperate rain forest of the Southern Hemisphere. Recently, Matsubara et al. (2008) reported an increase in Lut content in response to excess light that may enhance photoprotection in leaves of tropical tree species. It has been reported that $\mathrm{Z}$ could be equivalent to Lut in energy dissipation in Quercus ilex subsp. ballota (García-Plazaola et al. 2002, Corcuera et al. 2005). Nevertheless, our results showed extremely high leaf lutein levels in summer without a concomitant increase in NPQ at saturating light. It is likely that $500 \mu \mathrm{mol}$ photons $\mathrm{m}^{-2} \mathrm{~s}^{-1}$ (a value much lower compared to the summer natural levels), was not enough to trigger the whole NPQ plant capability. Further studies using over saturating or even photoinhibitory photon fluxes will be necessary to clarify the NPQ and Lut relationship.

The frequently higher total $\mathrm{Chl}$ contents on a fresh mass basis in L. ferruginea and a lower $\mathrm{Chl} \mathrm{a} / \mathrm{b}$ ratio agree well with its shady habitat preferences (Table 4). This has been previously observed in other umbrophyllous plants in relation to those growing in more illuminated 
places (Evans 1988, Logan et al. 1998). The $\mathrm{Chl} \mathrm{a} / \mathrm{b}$ ratio is smaller in shade acclimated leaves, which have more chlorophyll associated with the light harvesting complex (LHC) than with the reaction centres (Evans 1988). Thus, a decreased $\mathrm{Chl} a / b$ ratio may be the result of a greater investment in the LHC in the umbrophyllous L. ferruginea. A positive correlation was found between the $\mathrm{Chl}$ a/b ratio and the light percentage (with respect to the open field) that the species received in their microhabitats $\left(r_{s}=0.78 \mathrm{P} \leq 0.05\right)$. This corresponds well with the findings in sun and shade plants (Evans 1988).

The more evident differences between developmental stages of the studied species were found in some photochemical energy quenching parameters. In general, seedlings of the umbrophyllous species increased their photosynthetic parameters as they reached adulthood (Table 2). This may be relevant to the transition from shade to a more lighted environment that seedlings undergo as they reach adulthood, as suggested for $N$. nitida (Coopman et al. 2008). Thus, this plant changes the balance of light energy utilization during its development, supporting its capacity to grow in more illuminated environments. The small differences in net photosynthesis at $500 \mu \mathrm{mol}$ photons $\mathrm{m}^{-2} \mathrm{~s}^{-1}$ (Fig. 2) in contrast to differences in ETR values at midday (Table 2) found among developmental stages of $L$. ferruginea suggest that other photochemical processes, such as Mehler reaction or photorespiration, are occurring (Pérez-Torres et al. 2007). This was not always the case for the heliophyte, which appears to decrease these parameters in adults in summer with respect to the seedling stage. Therefore, it is difficult to predict adult photosynthetic performance from measurements made in seedlings. Nonetheless, these parameters and photosynthesis rate reflected the typical differences between sun and shade species at the seedling stage, with higher values of net photosynthesis, ФPSII, qP, and ETR in E. coccineum (sun plant) than $L$. ferruginea (shade plant). These species showed a similar response when growing at similar light intensity in the laboratory (Castro-Arévalo et al. 2008).

Thus, we concluded that the shade intolerant E. coccineum was able to use more absorbed energy in net photosynthesis throughout its life cycle than the shade species. This is consistent with the pioneer character, higher growth rate, and wide altitudinal and latitudinal distribution of E. coccineum compared to $L$. ferruginea. $L$. ferruginea adjusts its photochemical attributes (qP, ETR, and ФPSII) during its transition from seedling to adulthood, which allows it to recruit in the shade and further survive in a more lighted environment. These photosynthetic attributes may be pivotal for recruitment and the succession status of a species in terms of pioneer or climax regeneration strategies.

\section{ACKNOWLEDGMENTS}

The support of FONDECYT 1050640 is gratefully acknowledged.

\section{LITERATURE CITED}

ADAMS WWIII \& B DEMMIG-ADAMS (1994) Carotenoid composition and downregulation of photosystem II in three conifer species during the winter. Physiologia Plantarum 92: 451-458.

ADAMS WWIII, B DEMMIG-ADAMS, AS VERHOEVEN \& DH BARKER (1995) Photoinhibition during winter stress: involvement of sustained xanthophylls cycle-dependent energy dissipation. Australian Journal of Plant Physiology 22: 261-276.

ADAMS WWIII \& DH BARKER (1998) Seasonal changes in xanthophyll cycle-dependent energy dissipation in Yucca glauca Nuttall. Plant, Cell, Environment 21: 501-511.

ADAMS WWIII, B DEMMIG-ADAMS, BA LOGAN, DH BARKER \& CB OSMOND (1999) Rapid changes in xanthophyll cycle-dependent energy dissipation and photosystem II efficiency in two vines, Stephania japonica and Smilax australis, growing in the understory of an open Eucalyptus forest. Plant, Cell, Environment 22: 125-136.

ADAMS WWIII, B DEMMIG-ADAMS, TN ROSENSTIEL, AK BRIGHTWELL \& V EBBERT (2002) Photosynthesis and photoprotection in overwintering plants. Plant Biology 4: 545-557.

ADAMS WWIII, CR ZARTER V, EBBERT, \& B DEMMIG-ADAMS (2004) Photoprotective strategies of overwintering evergreens. Bioscience 54: 41-49.

ALBERDI M, \& C DONOSO (2004) Variabilidad en Embothrium coccineum. In: Donoso C, A Premoli, L Gallo \& R Ipinza (eds) Variación intraespecífica en las especies arbóreas de los bosques templados de Chile y Argentina: 345-356. Editorial Universitaria, Santiago, Chile.

BILGER W \& O BJÖRKMAN. (1990) Role of the xanthophyll cycle in photoprotection elucidated by measurement of light-induced absorbance changes, fluorescence and photosynthesis in Hedera canariensis. Photosynthesis Research 25: 173-175.

BJÖRKMAN O \& SB POWLES (1984) Inhibition of 
photosynthesis reactions under water stress: Interactions with light level. Planta 161: 490-504.

BJÖRKMAN O \& B DEMMIG (1987) Photon yield of $\mathrm{O}_{2}$ evolution and chlorophyll fluorescence characteristics at $77 \mathrm{~K}$ among vascular plants of diverse origins. Planta 170: 489-504.

CASTRO-ARÉVALO M, M REYES-DÍAZ, M ALBERDI, V JARA-RODRÍGUEZ, SANHUEZA C, LJ CORCUERA \& LA BRAVO (2008) Effects of low temperature acclimation on photosynthesis in three Chilean Proteaceae. Revista Chilena de Historia Natural 81: 321-333

COOPMAN R, M REYES-DÍAZ, VF BRICEÑO, LJ CORCUERA, CABRERA HM \& LA BRAVO. (2008) Changes during early development in photosynthetic light acclimation capacity explain the shade to sun transition in Nothofagus nitida. Tree Physiology 28:1561-1571.

CORCUERA L, F MORALES, A ABADÍA \& E GILPELEGRIN (2005) Seasonal changes in photosynthesis and photoprotection in a Quercus ilex subsp. ballota woodland located in its upper altitudinal extreme in the Iberian Peninsula. Tree Physiology 25: 599-608.

DEMMIG-ADAMS B, \& WWIII ADAMS. (1992) Photoprotection and other responses of plants to high light stress. Annual Review of Plant Physiology and Plant Molecular Biology 43: 599626.

DEMMIG-ADAMS B \& WWIII ADAMS (1996) Xantophyll cycle and light stress in nature: uniform response to excess direct sunlight among higher plant species. Planta 198: 460-470.

DEMMIG-ADAMS B (2003) Linking the xanthophylls cycle with thermal energy dissipation. Photosynthesis Research 76: 73-80.

EVANS JR (1988) Acclimation by the thylakoid membranes to growth irradiance and the partitioning of nitrogen between soluble and thylakoid proteins. Australian Journal of Plant Physiology 15: 93-106.

GARCÍA-PLAZAOLA JI, A HERNÁNDEZ, E ERRASTE \& JM BECERRIL (2002) Occurrence and operation of lutein epoxide cycle in Quercus species. Functional Plant Biology 29: 1075-1080.

GARCÍA-PLAZAOLA JI, JM OLANO, AJ HERNÁNDEZ \& M BECERRIL (2003) Photoprotection in evergreen Mediterranean plants during sudden periods of intense cold weather. Trees 17: 285-291.

GENTY B, BRIANTAIS JM \& NR BAKER (1989) The relationship between the quantum yield of photosynthetic electron transport and quenching of chlorophyll fluorescence. Biochimica et Biophysica Acta 990: 87-92.

GILMORE AM \& HY YAMAMOTO (1991) Resolution of lutein and zeaxanthin using a non-endcapped, lightly carbon-loaded $\mathrm{C}_{18}$ high-performance liquid chromatographic column. Journal of Chromatographie 543: 137-145.

GILMORE AM \& HY YAMAMOTO (1993) Linear models related xanthophyll and lumen acidity to non-photochemical fluorescence quenching. Evidence that antheraxanthin explains zeaxanthinindependent quenching. Photosynthesis Research 35: 67-78.

GILMORE AM \& MC BALL (2000) Protection and storage of chlorophyll in overwintering evergreens. Proceedings of the National Academy of Sciences USA 97: 11098-11101.

HORMAETXE K, JM BECERRIL, A HERNÁNDEZ, R ESTEBAN \& JI GARCÍA-PLAZAOLA (2007)
Plasticity of photoprotective mechanisms of Buxus sempervirens L. leaves in respose to extreme temperatures. Plant Biology 9: 59-68.

HUNER NPA, AG IVANOV, KE WILSON, MM KROLL \& G ÖQUIST (2002) Energy sensing and phototaxis in photoautrophs. In: Storey KB \& JM Storey (eds) Cell and molecular responses to stress: Sensing signalling and cell adaptation: 243-255. Elsevier Science, Amsterdam, The Netherlands.

IVANOV AG, PV SANE, Y ZEINALOV, G MALMBERG, P GARDESTRÖM, NPA HUNER \& G ÖQUIST (2001) Photosynthetic electron transport adjustments in over wintering Scots pine (Pinus silvestris L.). Planta 213: 575-585.

JOHNSON GN, AJ YOUNG, JD SCHOLES \& P HORTON (1993) The dissipation of excess excitation energy in British plant species. Plant, Cell, Environment 16: 673-679.

KITAO M, TT LEI, T KOIKE, H TOBITA \& Y MARUYAMA (2000) Susceptibility to photoinhibition of three deciduous broadleaf tree species with different successional traits raised under various light regimes. Plant, Cell, Environment 23: 81-89.

KRAUSE GH \& K WINTER (1996) Photoinhibition of photosynthesis in plants growing in natural tropical forest gaps. A chlorophyll fluorescence study. Botanica Acta 109: 456-462.

KÜLHEIM C, J ÅGREN \& S JANSSON (2002) Rapid regulation of light harvesting and plant fitness in the field. Science 297: 91-93.

LICHTENTHALER HK \& AR WELLBURN (1983) Determinations of total carotenoids and chlorophyll $\mathrm{a}$ and $\mathrm{b}$ of leaf extracts in different solvents. Biochemical Society Transactions 603: 591-592.

LOGAN BA, SC GRACE, WWIII ADAMS \& B DEMMIG-ADAMS (1998) Seasonal differences in xanthophyll cycle characteristics and antioxidants in Mahonia repens growing in different light environments. Oecologia 116: 9-17.

MATSUBARA S, GH KRAUSE, M SELTMANN, A VIRGO, TA KURSAR, P JAHNS \& K WINTER (2008) Lutein epoxide cycle, light harvesting and photoprotection in species of the tropical tree genus Inga. Plant, Cell, Environment 31: 548-561.

MAXWELL K \& GN JOHNSON (2000) Chlorophyll fluorescence-a practical guide. Journal of Experimental Botany 51: 659-668.

MC QUEEN DR (1977) The ecology of Nothofagus and associated vegetation in South America. Tuatara 22: 233-244.

MOHAMMED GH, PJ ZARCO-TEJEDA \& JR MILLER (2003) Practical applications of chlorophyll fluorescence. In: DeEll JR \& PMA Toivonen (eds) Practical applications of chlorophyll fluorescence in plant biology: 79-124. Kluwer Academic Publisher, Massachusetts.

NIYOGI KK (1999) Photoprotection revisited: genetic and molecular approaches. Annual Review of Plant Physiology and Plant Molecular Biology 50: 333359.

OTTANDER C, D CAMPBELL \& G ÖQUIST (1995) Seasonal changes in photosystem II organization and pigment composition in Pinus silvestris. Planta 197: 176-183.

PÉREZ-TORRES E, L BASCUÑÁN, A SIERRA, LA BRAVO \& LJ CORCUERA (2006) Robustness of activity of Calvin cycle enzymes after high light and low temperature conditions in Antarctic vascular plants. Polar Biology 29: 909-916. 
PÉREZ-TORRES E, LA BRAVO, LJ CORCUERA \& GN JOHNSON (2007) Is electron transport to oxygen an important mechanism in photoprotection? Contrasting responses from Antarctic vascular plants. Physiologia Plantarum 130: 185-194.

REYES-DÍAZ M, M ALBERDI, F PIPER, LA BRAVO \& LJ CORCUERA (2005). Low temperature responses of Nothofagus dombeyi (Mirb.) Blume and Nothofagus nitida (Phil.) Krasser, two evergreen species from South Central Chile. Tree Physiology 25: $1389-1398$.

SAVITCH LV, ED LEONARDOS, M KROL, S JANSSON, B GRODZINSKI, NPA HUNER \& G ÖQUIST (2002) Two different strategies for light utilization in photosynthesis in relation to growth and cold acclimation. Plant, Cell, Environment 25: 761-771.

SCHREIBER U, BILGER W \& C NEUBAUER (1994) Chlorophyll fluorescence as a non intrusive indicator for rapid assessment of in vivo photosynthesis. In: Schluze ED \& MM Cadwell (eds) Ecophysiology of photosynthesis: 49-70. Springer Verlag, Berlin, Germany.

ŠTROCH M, K KULDOVÁ, J KALINA \& V ŠPUNDA (2008) Dynamics of the xanthophylls cycle and nonradiative dissipation of absorbed light energy during exposure of Norway spruce to high irradiance. Journal of Plant Physiology 165: 612-622.

SULLIVAN JH \& J ROZEMA (1999) UV-B effects on terrestrial plant growth and photosynthesis. In: Rozema J (ed) Stratospheric ozone depletion. The effects of enhanced UV-B radiation on terrestrial ecosystems: 39-57. Backhuys Publishers, Leiden, The Netherlands.

TAUSZ M, CR WARREN \& MA ADAMS (2005) Dynamic light use and protection from excess light in upper canopy and coppice leaves of Nothofagus cunninghamii in an old growth, cool temperate rainforest in Victoria, Australia. New Phytologist 165: 143-156.

VALLADARES F, I DOBARRO, D SÁNCHEZ-GÓMEZ \& RW PEARCY. (2005) Photoinhibition and drought in Mediterranean woody saplings: scaling effects and interactions in sun and shade phenotypes. Journal of Experimental Botany 56: 483-494.

VERHOEVEN AS, WW ADAMS \& B DEMMIG-ADAMS (1999) The xanthophyll cycle and acclimation of Pinus ponderosa and Malva neglecta to winter stress. Oecologia 118: 277-287.

WEINBERGER P (1974) Verbreitung und Wasserhaushalt araucano-patagonischer Proteaceen in Beziehung zu mikroklimastischen Faktoren. Flora 163: 251-264.

YOO SD, DH GREER, WA LAING \& MT MCMANUS (2003) Changes in photosynthetic efficiency and carotenoid composition in leaves of white clover at different developmental stages. Plant Physiology and Biochemistry 41: 887-893.

ZÚÑIGA R, M ALBERDI, M REYES-DÍAZ, E OLIVARES, S HESS, LA BRAVO \& LJ CORCUERA (2006) Seasonal changes in the photosynthetic performance of two evergreen Nothofagus species in South Central Chile. Revista Chilena de Historia Natural 79: 489-504. 